\title{
Progesterone secretion by the corpus luteum of the early pregnant pig during superfusion in vitro with PGF-2 $\alpha, \mathrm{LH}$ and oestradiol
}

\author{
J. Watson and Felicity M. Maule Walker* \\ Department of Biochemistry, University of Strathclyde, Todd Centre, \\ 31 Taylor Street, Glasgow G4 ONR, U.K.
}

\begin{abstract}
Summary. Corpora lutea obtained from pregnant sows (Days 18-22) were superfused in vitro for $2-4 \mathrm{~h}$ with PGF-2 $\alpha$ and for $3 \mathrm{~h}$ with $\mathrm{LH}$ or oestradiol or combinations of PGF-2 $\alpha$ with LH or oestradiol. LH but not oestradiol stimulated progesterone secretion while superfusion for a minimum of $3 \mathrm{~h}$ with PGF- $2 \alpha$ caused an irreversible decrease in progesterone secretion. $\mathrm{LH}$ and PGF- $2 \alpha$ were mutually antagonistic while oestradiol did not inhibit the luteolytic action of PGF-2 $\alpha$.
\end{abstract}

\section{Introduction}

In the pig, prostaglandin (PG) F-2 $\alpha$ fails to cause luteolysis when administered before Day 12 of the oestrous cycle (Diehl \& Day, 1974; Moeljono, Bazer \& Thatcher, 1976). After Day 12, however, luteolysis can be induced by PGF-2 $\alpha$ (Moeljono et al., 1976) or by a synthetic analogue, ICI 79,939 (Guthrie \& Polge, 1976). PGF-2 $\alpha$ also causes regression of corpora lutea maintained beyond the normal luteal phase of the oestrous cycle by oestradiol benzoate treatment (Kraeling, Barb \& Davis, 1975). These studies suggest that the sensitivity of the pig corpus luteum to PGF- $\alpha$ increases as the corpus luteum ages and that young corpora lutea are refractory to luteolytic agents. In pregnant pigs luteolysis can be induced by PGs from Day 23 of gestation onwards (Diehl \& Day, 1974) and effective doses of PGs cause abortion because the ovaries are necessary for the maintenance of pregnancy throughout gestation (du Mesnil du Buisson \& Dauzier, 1957). The present study was designed to test, by superfusion in vitro, the effects of PGF-2 $\alpha$ on progesterone secretion by luteal tissue of early pregnant pigs.

\section{Materials and Methods}

The ovaries and uteri were obtained from pregnant sows known to have mated 18-22 days before slaughter. The organs were immediately placed in chilled medium 199 and transported to the laboratory. Pregnancy was confirmed by flushing the uterus with medium 199 and checking for the presence of embryos. The corpora lutea were carefully excised, trimmed free of connective tissue and sliced to a thickness of $0.4 \mathrm{~mm}$ with a hand microtome.

The superfusion technique was that previously described (Watson \& Maule Walker, 1977) and basically consists of pumping medium 199, or medium containing test substances, through a known weight of luteal tissue in small columns (volume $2.5 \mathrm{ml}$ ) and collecting the effluent (superfusate) for selected time intervals by means of a fraction collector. The whole system was completely closed and maintained at $4^{\circ} \mathrm{C}$ to ensure sterility. The input medium was heated to $37^{\circ} \mathrm{C}$ by passage through glass coils in a water bath at $37^{\circ} \mathrm{C}$ which also contained the superfusion chambers. The test substances, LH (NIH-LH-69), PGF-2 $\alpha$ (Upjohn) or oestradiol (Sigma), were always present at concentrations of $1 \mu \mathrm{g} / \mathrm{ml}$ superfusing medium, and the solutions were superfused over the tissue for $2 \mathrm{~h}$ ( 3 experiments), $3 \mathrm{~h}$ ( 5 experiments) or $4 \mathrm{~h}$ ( 2 experiments) at a flow rate of $20 \mathrm{ml} / \mathrm{h}$. When combinations of LH or oestradiol with PGF- $2 \alpha$ were used, both materials were present in the medium

\footnotetext{
* Present address: A.R.C. Institute of Animal Physiology, Babraham, Cambridge, U.K.
} 
at concentrations of $1 \mu \mathrm{g} / \mathrm{ml}$ medium and these 3 experiments were carried out for $3 \mathrm{~h}$ only. All experiments and appropriate controls were performed at least in duplicate with tissue from each animal. Progesterone levels were measured in triplicate in duplicate aliquots of each superfusate by a combination of a selective extraction technique and a highly specific double-antibody radioimmunoassay method (Watson \& Maule Walker, 1977). The inter-assay coefficient of variation was $6.5 \%$ and the intra-assay coefficient of variation $5.6 \%$. Blank sample values were always $<5 \mathrm{pg}$ progesterone $/ \mathrm{ml}$ medium 199 and were therefore disregarded.

\section{Results}

The patterns of progesterone secretion in vitro from luteal tissue of the early pregnant pig during control superfusion with medium only and during treatment with LH and PGF-2 $\alpha$ are shown in Text-fig. 1(a). Secretion of the steroid from the control tissue was relatively steady over the experimental period. The presence of $\mathrm{LH}$ in the superfusion medium produced, as expected, considerable stimulation of progesterone secretion and the pattern was similar to that noted previously for nonpregnant pigs (Watson \& Leask, 1975; Watson \& Wrigglesworth, 1975) in that there was a rapid transient increase in progesterone secretion (attributed to release of preformed steroid) followed by a prolonged stimulation of the steroid which lasted throughout the remainder of the experimental period. This response to $\mathrm{LH}$ was similar with tissue from all the animals studied and for all the times used (2-4 h). PGF-2 $\alpha$, when superfused for $3 \mathrm{~h}$ (Text-fig. 1a) or more, caused a drop in progesterone secretion $(65-75 \%$ relative to controls) which persisted throughout the remainder of the experimental period, although there was a rise in progesterone secretion $(55-65 \%$ inhibition relative to controls) about $3 \mathrm{~h}$ after the start of the infusion (Text-fig. 1a). When the tissue was superfused with PGF- $2 \alpha$ for only $2 \mathrm{~h}$ there was again a drop in progesterone secretion, but the concentrations returned to control values immediately the superfusion ended. Unlike luteal tissue from the nonpregnant pig, which showed a dose-dependent response to PGF-2 $\alpha$ with lower doses being more effective (Watson \& Maule Walker, 1977), all doses of PGF-2 $\alpha$ used $(0 \cdot 1-5 \mu \mathrm{g} / \mathrm{ml})$ gave a similar response with pregnant pig luteal tissue.

The effects of superfusion with oestradiol, oestradiol + PGF-2 $\alpha$ or LH + PGF-2 $\alpha$ are shown in Text-fig. 1(b). Oestradiol alone had no effect on progesterone secretion, and when present with PGF-2 $\alpha$ did not influence the inhibitory effect of PGF-2 $\alpha$ on progesterone secretion. In the presence of LH, PGF-2 $\alpha$ had no inhibitory effect on progesterone secretion; although the steroid appeared to be secreted as a series of large pulses, the mean value was not significantly different from that of secretion during control superfusion. The presence of PGF- $2 \alpha$ did, however, eliminate the stimulatory effect of $\mathrm{LH}$ which was seen in Text-fig. 1(a).

\section{Discussion}

These results demonstrate that the corpus luteum of the early pregnant pig is susceptible to the luteolytic effect of PGF- $2 \alpha$ in vitro, although a minimum exposure of at least $3 \mathrm{~h}$ appears to be needed to cause an irreversible decrease in progesterone secretion. The decrease of $65-75 \%$ in progesterone secretion from the PGF-2 $\alpha$-treated tissue relative to the control tissue is in good agreement with the results of Diehl \& Day (1974) who observed a similar decline $(76 \%)$ in plasma progesterone concentrations in 25-30 Day pregnant gilts $12 \mathrm{~h}$ after injection of PGF-2 $\alpha$. Diehl \& Day (1974) also observed a transient peak in progesterone concentration following injection of PGF- $2 \alpha$, but by $4 \mathrm{~h}$ after treatment plasma concentrations of progesterone had decreased by $40 \%$ and 4 of the 7 gilts studied aborted 24-32 h after treatment. It therefore appears that functional luteolysis of these early pregnant pig corpora lutea has been achieved by a 3-h exposure to PGF- $2 \alpha$. Since a 5-h exposure to PGF-2 $\alpha$ of luteal tissue from cyclic pigs (Day 11-14) did not cause luteolysis (Watson \& Maule Walker, 1977), the present results support the belief that 'early' corpora lutea are refractory to the effects of PGF- $2 \alpha$ while those maintained beyond their normal cyclic life-span are particularly susceptible to PGF-2a. 


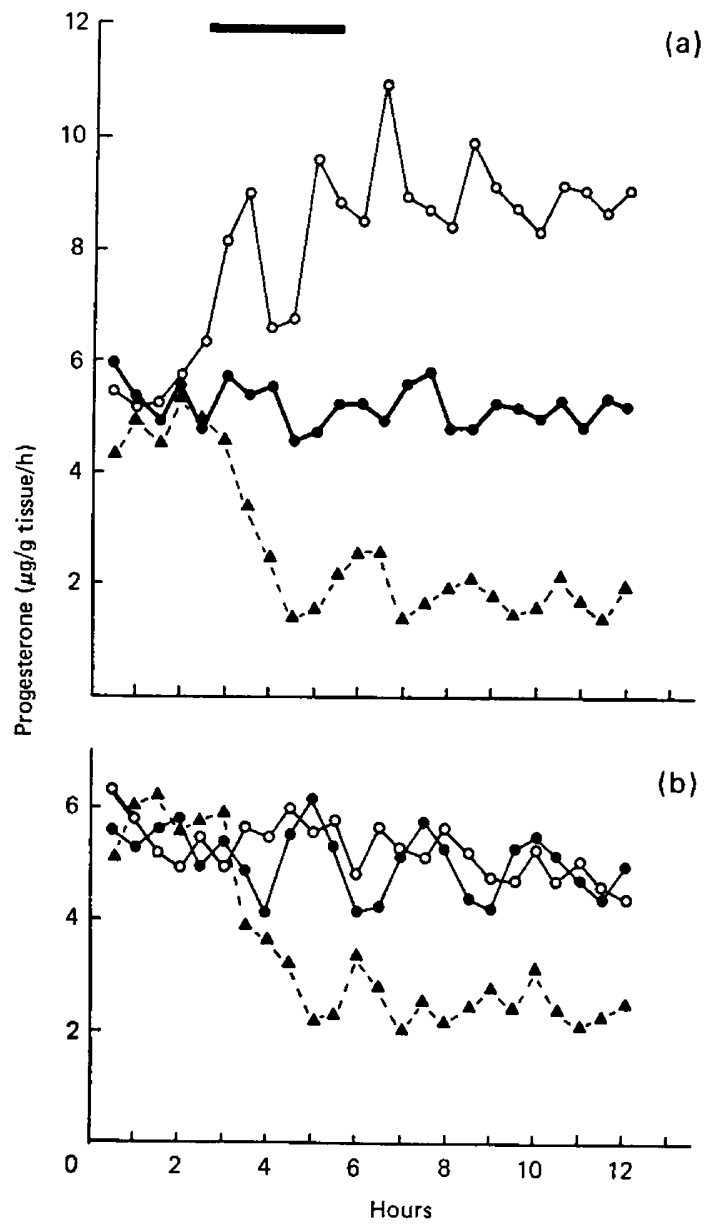

Text-fig. 1. Progesterone secretion by luteal tissue of early pregnant pigs during superfusion in vitro. The horizontal bar represents the period when test materials were present in the superfusing medium. Each point represents 5 (a) or 3 (b) experiments; s.e.m. values did not exceed $\pm 0.6 \mu \mathrm{g} / \mathrm{g}$ tissue/h at any point. (a) •, Control; 0 , LH (1 $\mu$ g NIH-LH-B9/ml medium); $\Delta$, PGF-2 $\alpha$ (1 $\mu \mathrm{g} \mathrm{PGF-2 \alpha /ml} \mathrm{medium).} \mathrm{(b)} O$, oestradiol (1 $\mu \mathrm{g} / \mathrm{ml}) ; \Delta$, PGF-2 $\alpha+$ oestradiol $(1 \mu \mathrm{g}$ PGF-2 $\alpha+1 \mu \mathrm{g}$ oestradiol/ml);, PGF-2 $\alpha+\mathrm{LH}$ (1 $\mu \mathrm{g} \mathrm{PGF}-2 \alpha+1 \mu \mathrm{g} \mathrm{LH} / \mathrm{ml})$.

Protection of the early pregnant pig corpus luteum from the luteolytic actions of PGF-2 $\alpha$ was obtained by simultaneous infusions with LH but not with oestradiol, suggesting that oestradiol has no direct luteotrophic role on pig ovarian tissue at the times studied. Heap, Perry, Gadsby \& Burton (1975) have suggested that the sudden onset of oestrogen synthesis by the pig blastocyst between Days 10 and 12 post coitum, coinciding with the time of maternal recognition of pregnancy, may act as an embryonic signal to prolong luteal function at this time. The present demonstration of a lack of a direct luteotrophic action for oestradiol on the corpus luteum of the early pregnant pig (Days 18-22) suggests that an embryonic oestradiol signal is relatively short-lived and that the primary action of the steroid is probably its ability to cause LH release (Henricks, Guthrie \& Handlin, 1972; Robertson \& King, 1974; Perry et al., 1976).

In the rat, PGF-2 $\alpha$ causes a marked fall in serum progesterone and in the capacity of luteal tissue to bind hCG (Grinwich, Ham, Hichens \& Behrman, 1976; Behrman \& Hichens, 1976). These results have been used to suggest that luteolysis may occur because of loss of luteal gonadotrophin binding. The present results, showing loss of the stimulatory activity of LH on progesterone secretion 
from the pregnant pig corpus luteum in the presence of PGF-2 $\alpha$, support this hypothesis. However, the observed protection by LH from the luteolytic action of PGF-2 $\alpha$ is more difficult to interpret although a similar action has been reported for the pseudopregnant rat (Behrman, Yoshinaga \& Greep, 1971) and for cultured human granulosa cells (Henderson \& McNatty, 1975). It is possible that slow dissociation of LH from its receptor (Henderson \& McNatty, 1975), followed by an inability of these receptors to bind LH in the presence of PGF-2 $\alpha$ (Behrman \& Hichens, 1976), could normally account for luteolysis but that in the present system the presence of excess LH with the PGF-2 $\alpha$ prevented dissociation of the LH from its receptor and thus inhibited the luteolytic effect.

We thank Miss Ruth MacCormack and Mrs Joanne Raeburn for extensive technical assistance; Dr R. H. F. Hunter, Edinburgh for the material; the National Institutes of Health, Bethesda, Maryland, U.S.A., for the LH; Dr J. E. Pike, Upjohn, U.S.A. for the PGF-2 $\alpha$; and particularly the M.R.C. for fina ncial support.

\section{References}

Behrman, H.R. \& Hichens, M. (1976) Rapid block of gonadotrophin uptake by corpora lutea in vivo induced by prostaglandin F-2 $\alpha$. Prostaglandins 12 , 83-95.

Behrman, H.R., Yoshinaga, K. \& Greep, R.O. (1971) Extra luteal effects of prostaglandins. Ann. N.Y. Acad. Sci. 180, 426-435.

DiEHL, J.R. \& DAY, B.N. (1974) Effect of prostaglandin $\mathrm{F}_{2 \alpha}$ on luteal function in swine. J. Anim. Sct. 39, 392-396.

du Mesnil du Buisson, F. \& Dauzier, L. (1957) Influence de l'ovariectomie chez la truie pendant la gestation. C. r. Séanc. Soc. Biol. 151, 311-313.

Grinwich, D.L., Ham, E.A., Hichens, M. \& Behrman, H.R. (1976) Binding of human chorionic gonadotrophin and response of cyclic nucleotides to luteinizing hormone in luteal tissue from rats treated with prostaglandin F-2a. Endocrinology 98, 146-150.

Guthrie, H.D. \& Polge, C. (1976) Luteal function and oestrus in gilts treated with a synthetic analogue of prostaglandin $\mathrm{F}_{2 \alpha}$ (ICI 79,939) at various times during the oestrous cycle. J. Reprod. Fert. 48, 423-425.

Heap, R.B., Perry, J.S., Gadsby, J.E. \& Burton, R.D. (1975) Endocrine activities of the blastocyst and early embryonic tissue in the pig. Biochem. Soc. Trans. 3, 1183-1188.

Henderson, K.M. \& McNatty, K.P. (1975) A biochemical hypothesis to explain the mechanism of luteal regression. Prostaglandins 9, 779-797.
Henricks, D.M., Guthrie, H.D. \& Handlin, D.L. (1972) Plasma estrogen, progesterone and luteinizing hormone levels during the estrous cycle in pigs. Biol. Reprod. 6, 210-218.

Kraeling, R.R., BARB, C.R. \& Davis, B.J. (1975) Prostaglandin induced regression of porcine corpora lutea. Prostaglandins 9, 459-462.

Moeljono, M.P.E., Bazer, F.W. \& Thatcher, W.W. (1976) A study of prostaglandin $F_{2 \alpha}$ as the luteolysin in swine. 1. Effect of prostaglandin $F_{2 \alpha}$ in hysterectomised gilts. Prostaglandins 11, 737-743.

Robertson, H.A. \& KING, G.J. (1974) Plasma concentrations of progesterone, oestrone, oestradiol-17 $\beta$ and of oestrone sulphate in the pig at implantation, during pregnancy and at parturition.J. Reprod. Fert. 40, 133-142.

Perry, J.S., Heap, R.B., Burton, R.D. \& Gadsby, J.E. (1976) Endocrinology of the blastocyst and its role in the establishment of pregnancy. J. Reprod. Fert., Suppl. 25, 85-104.

WATSON, J. \& LEASK, J.T.S. (1975) Superfusion in vitro in the study of ovarian steroidogenesis. $J$. Endocr. 64, 163-173.

Watson, J. \& Maule Walker, F.M. (1977) The effect of prostaglandin F-2 $\alpha$ and uterine extracts on progesterone secretion in vitro by superfused pig corpora lutea. J. Reprod. Fert. 51, 393-398.

Watson, J. \& Wrigglesworth, P.M. (1975) Progesterone synthesis by pig corpus luteum tissue during superfusion. Biochem. J. 150, 301-304. 